\title{
Museus e revitalização urbana: o Museu de Artes e Ofícios e a Praça da Estação em Belo Horizonte*
}

\author{
Museums and urban revitalization: Museu de Artes \\ e Ofícios and Praça da Estação in Belo Horizonte
}

Felipe Eleutério Hoffman

\begin{abstract}
Resumo
Uma das condições principais em que se observa o nascimento de novos espaços museológicos são os museus implantados durante os chamados processos de revitalização urbana. Se o que se pretende com essas iniciativas é dar "nova vida" a espaços antes considerados "degradados", cabe se perguntar qual o papel que essas instituições têm a desempenhar nesses processos. Observando que no Brasil, no final do século XX e início do atual, se desenvolveram diversas propostas e projetos de requalificação urbana, selecionaram-se, como alvo da presente reflexão, o processo de implantação do Museu de Artes e Ofícios (MAO) e sua correlação com os processos de revitalização urbana de parte da região central da cidade de Belo Horizonte.
\end{abstract}

Palavras-chave: museu; cidade; revitalização urbana; Praça da Estação; Museu de Artes e Ofícios.

\begin{abstract}
One of the main conditions in which the birth of new museums is observed are the museums that are implemented during the urban revitalization process. If what is intended with these initiatives is to give "new life" to areas that were previously considered "degraded", it is worth asking what role these institutions should play in these processes. In view of the fact that in Brazil, in the late twentieth century and in the beginning of the current century, several urban regeneration proposals and projects were developed, we selected the process of implementation of the Museu de Artes e Ofícios (Museum of Arts and Trades - MAO) as the target of the present investigation, as well as its connection with the urban revitalization process of part of the central region of the city of Belo Horizonte.
\end{abstract}

Keywords: museum; city; urban revitalization; Praça da Estação (Station Square); Museu de Artes e Ofício. 


\section{Introdução}

0 papel dos museus no mundo tem sido alvo das mais diversas análises ao longo dos anos, principalmente no mundo contemporâneo em que esse papel tem sido cada vez mais alvo de diversos questionamentos. As formas de representação do "outro", o distanciamento entre o museu e público, que muitas vezes os considera lugar de "coisa velha" são apenas algumas das questões com as quais os museus devem lidar na contemporaneidade. No entanto, como colocado por Tostes (2004, p. 5), "a importância dos museus no mundo contemporâneo não pode ser negada, e muito menos ignorada", o que se pode notar é que, mesmo sendo questionados, os museus continuam em voga como espaço público (Huyssen, 2004, p. 101). De fato, as instituições museológicas continuam a se reinventar, remodelar, e até mesmo novos museus continuam a surgir.

Dentre as condições em que se observam o nascimento de novos espaços museológicos, se encontram principalmente na relação destes com o espaço urbano, os museus implantados durante os chamados processos ou operações de revitalização urbana. Se o que se pretende com essas iniciativas é dar nova vida a espaços antes considerados degradados e problemáticos, sobre diversos aspectos, cabe aqui o questionamento sobre qual tem sido o papel desempenhado por essas instituições nesses processos.

Observando que no Brasil, no final do século $X X$ e início do atual, se desenvolveram diversas propostas e projetos de requalificação urbana, coube selecionar, como alvo da presente reflexão, uma das regiões em questão que compreende parte da região central da cidade de Belo Horizonte, mais especificamente a região da Praça Rui Barbosa, popularmente conhecida como Praça da Estação. 0 processo de revitalização pelo qual essa passou em tempos recentes e sua integração com a implantação do Museu de Artes e Ofícios (MAO) podem nos ser úteis para evidenciar novas perspectivas no relacionamento museu e espaço urbano requalificado.

Num primeiro momento serão abordados os processos de revitalização urbana e sua conceituação, apontando algumas problemáticas inerentes a tais processos e a incorporação da cultura e das instituições museológicas nessas propostas. Em seguida, serão tratadas a inserção do MAO na proposta de revitalização da Praça da Estação, bem como as dinâmicas de inclusão e exclusão presentes no processo. Por fim, objetiva-se elencar os saldos advindos da implantação dessa instituição à luz das questões abordadas anteriormente, buscando entender o papel dessa instituição em meio ao espaço urbano revitalizado.

\section{Processos de gentrificação em meio à musealização}

0 conceito de revitalização é comumente associado à tentativa de dinamizar antigas áreas centrais, readaptando-as à função do presente, sendo recorrentes em discursos de gestores e profissionais do urbanismo, ensejando planos e propostas de mudança, geralmente ocorrendo nas zonas centrais de cidades, mas não restritas a elas (Barreira, 2010). Às vezes encontrada sobre a forma de requalificação, a revitalização 
costuma designar intervenções realizadas com vistas a conferir aos espaços públicos formas dinâmicas de utilização, baseadas em investimentos comumente associados ao comércio e lazer. Nessa direção, segundo nos é apontado por Barreira (2010, p. 255), "Os espaços públicos passam a ser alvos de projetos que visam a recuperar zonas degradadas, imprimindo-lhes outras alternativas de utilização, oscilantes entre a afirmação de sentidos arcaicos e a incorporação de novos usos a antigas edificações".

Segundo alguns autores (Falcão, 2003; Botelho, 2005; Vargas e Castilho, 2006), as primeiras experiências teriam ocorrido no contexto do pós segunda Guerra Mundial, se intensificando nos anos de 1960 principalmente nos centros das grandes cidades norte-americanas e em algumas metrópoles europeias. Em decorrência de mudanças no planejamento das políticas urbanas e nos interesses do capital imobiliário, no início do século XX, ocorre um esvaziamento das regiões centrais das cidades. Ao longo da década de 1960, esses distritos centrais começam a ser lentamente reocupados por setores mais abastados da população, que retornam aos centros urbanos em busca de vantagens advindas das proximidades oferecidas por esses. Segundo Botelho (2005, p. 55):

Moradia, trabalho, lazer e consumo estavam disponíveis nos quarteirões vizinhos para aqueles que se dispusessem a morar no centro da cidade. Associava-se a isso o valor que se começava a agregar aos imóveis mais antigos, muitos deles considerados de interesse para preservação histórica.

Segundo Smith (1996 e 2003 apud BoteIho, 2005), o processo inicialmente era conduzido pelo mercado imobiliário, mas ao longo do tempo, precisamente nos anos 1990, tornou-se uma política urbana, uma estratégia articulada e global, fomentando diferentes modos de intervenção com o intuito de ordenar o espaço e devolver aos centros urbanos um papel hegemônico perdido. Tais operações passam a ser utilizadas para reforçar uma determinada imagem da cidade que passa a ser pensada não mais como um local de produção, mas como produto de consumo, uma mercadoria, isso se devendo principalmente ao desenvolvimento da comunicação e da propaganda. São introduzidas técnicas de planejamento estratégico associadas ao marketing urbano, que é potencializado principalmente devido à contribuição de uma arquitetura do espetáculo, na qual tem se construído obras monumentais, por arquitetos de renome (Oliveira, 2008, p. 8).

As propostas de revitalização têm ocupado papel de destaque na compreensão da dinâmica urbana na contemporaneidade dada a abrangência e frequência com que têm acontecido. "Nas últimas décadas, estes processos têm se caracterizado por incorporarem a cultura como conteúdo diferenciador das várias experiências de revitalização" (Botelho, 2005, p. 54). 0 uso da cultura tem se destacado como estratégia principal nos novos processos de revitalização urbana. Sua inserção nessas intervenções tem objetivado uma efetiva inclusão das metrópoles na competitiva rede global de cidades ditas culturais ou turísticas, com a promoção e venda de uma imagem da cidade como mercadoria. Principalmente através de uma patrimonialização ou museificação das próprias cidades, de seus centros ou monumentos históricos, que alguns autores passaram a denominar "culturalização" ou "musealização" das cidades (Huyssen, 2000). ${ }^{1}$ Esse contexto de 
mercantilização cultural decorre, entre outros fatores, de um processo de elitização do espaço: a gentrificação.

Em seu sentido original, a gentrification, ou gentrificação, "pressupõe uma reapropriação residencial (por grupos de maior poder aquisitivo), o que, algumas vezes, demanda a desapropriação de antigos moradores, nessas áreas centrais requalificadas" (Jayme e Neves, 2010, p. 611). Com a ampliação das iniciativas de revitalização de centros urbanos, bem como dos estudos em torno do tema, ocorre um alargamento do sentido do termo que passa a se estender não só sob o aspecto residencial, mas também as questões comerciais e de fluxo de pessoas. Portanto, além da gentrificação residencial, existe a gentrificação de consumo e de frequência, que será o centro da análise deste artigo.

Marcada por um caráter segregacionista, a gentrificação é fortemente criticada, pois promove uma destradicionalização das práticas locais na medida em que gera uma alteração dos sentidos atribuídos ao patrimônio, podendo inclusive acrescentar valores antes inexistentes (Leite, 2010). Essa importância econômica da cultura e o reconhecimento de seu papel na promoção da competitividade territorial das cidades têm originado uma progressiva culturalização das políticas urbanas. 0 que alguns autores têm identificado por meio de duas correntes principais, seja por congelamento, na criação de cidades-museu, ou através de uma patrimonialização desenfreada, seja por difusão, na produção de cidades genéricas e de uma urbanização generalizada. Nota-se que nessa ênfase dada à cultura nos planejamentos e processos urbanos tem-se observado predominantemente duas tendências que por vezes se misturam. A recuperação do ambiente histórico existente e a criação de equipamentos culturais como âncora do projeto, destacando-se entre esses equipamentos os museus e centros culturais (Vaz, 2004b, p. 229).

Desde sua implantação nas principais cidades europeias no século XVIII os museus sempre foram prédios diferenciados, de grande significado nos grandes centros urbanos. Nas últimas décadas, observa-se que boa parte dos novos museus tem se inserido em projetos cuja proposta pretende alterar o perfil socioeconômico de cidades ou regiões. Cabe destacar aqui que o conceito de museu sofreu grande expansão, principalmente no contexto pós segunda Guerra Mundial no qual a criação do Icom teve determinante influência, propiciando grandes avanços na mentalidade museal em resposta às demandas sociais do pós-guerra. ${ }^{2}$ As críticas aos museus, por movimentos que objetivavam uma democratização da cultura, fazem com que os museus deixem de ser espaços consagrados exclusivamente à cultura das elites, aos fatos e personagens excepcionais da história e passem a incorporar as questões relativas à vida cotidiana das comunidades, às lutas pela preservação do meio ambiente e à memória de grupos sociais específicos (Julião, 2006). Novas práticas e teorias sinalizavam uma função social do museu, que passava a redefinir seu papel tendo como objetivo maior o público, e não mais seu acervo, imprimindo aos museus uma função crítica e transformadora na sociedade, destacando-se o surgimento do conceito de ecomuseu e museu comunitário ${ }^{3}$ e o estabelecimento de um Movimento Internacional por uma Nova Museologia (Minom). Partindo dessas premissas, nota-se que a implantação de museus durante os chamados processos de revitalização urbana 
apresentam algumas características comuns que se repetem nos mais diversos contextos ao redor do globo.

Seja com novas construções ou adaptação de antigos marcos históricos, os museus constituem-se em marcos urbanos, e é justamente essa capacidade de atração e o seu simbolismo que têm levado os planejadores e urbanistas a utilizá-los como catalisadores nas operações urbanas. Isto sendo observado tanto do ponto de vista arquitetônico ou paisagístico, como a partir dos meios de comunicação através de uma veiculação midiática. 0 que corresponderia diretamente à necessidade já elencada de criação de uma imagem para a cidade e de sua consequente inserção em um mercado global, que frequentemente se dá atrelada à questão patrimonial, seja ela cultural ou natural, através da arquitetura de suas instituições culturais ou das formas de seu patrimônio natural. ${ }^{4}$

Uma segunda característica comum observada quando da implantação de museus nesses processos é a capacidade de gerar uma aglomeração de equipamentos e instituições culturais. Segundo Vaz, quando utilizados como âncoras do processo de revitalização urbana, "os equipamentos culturais tendem a definir uma espacialidade que lhes assegura uma irradiação sobre seu entorno" (2004b, p. 232). Dessa forma a instalação de um museu pode atrair atividades comerciais, bares, restaurantes, livrarias e outros equipamentos culturais, acabando por gerar uma espécie de "território cultural". Esse efeito pode surgir espontaneamente a partir de pessoas ou de grupos informais de produtores culturais que transformam o local em uma alternativa cultural, ou pode ser induzido, através de investidores privados que objetivam atrair determinado segmento de consumidores e novos habitantes, ou ainda através de um planejamento estatal com a intenção de fomentar a chamada economia criativa (Amazonas e Lima, 2010). Quando esse efeito é planejado, como geralmente ocorre em processos de revitalização urbana, esses recortes vêm sendo denominados "distritos culturais". Nas palavras de Vaz (2004b, p. 233), o distrito cultural caracteriza-se como uma "área espacialmente distinta e limitada que contém alta concentração de ofertas culturais" tanto em termos de consumo como de produção. Esse tipo de agrupamento seria capaz de produzir um impacto positivo sobre a produção cultural na medida em que propicia a interação, aprendizado, troca de experiências, competição e teste de ideias entre artistas e outros empresários culturais. Ao mesmo tempo apresentando um efeito sobre a melhora na qualidade de vida da comunidade local (Amazonas e Lima, 2010). ${ }^{5}$

Seja através de sua capacidade de marcar e valorizar o espaço urbano ou de seu potencial como um agregador de instituições culturais e investimentos, nota-se que o museu se apresenta como um forte atrativo turístico. Para alguns autores, essa capacidade de atingir uma massa crítica é inclusive considerada uma condição essencial para o sucesso dessas instituições (ibid.). Porém observa-se que a implantação de museus quando da execução de projetos de revitalização urbana, quando não atrelada a uma coesão, valorização, participação e desenvolvimento das comunidades e dos territórios envolvidos, corrobora o processo de gentrificação dos espaços. Resultando em políticas de enobrecimento do território, que modificam os significados das instituições 
museológicas, fazendo com que se tornem apenas atrativos com alto potencial turístico, em centros de lazer, transformando o patrimônio em mercadoria altamente valorizada (Botelho, 2005). Meneses nos lembra que a inserção da cultura como capital para projetos de recuperação e renovação urbana fizeram do museu uma alavanca essencial. Entretanto, verifica-se que o habitante tem sido marginalizado do processo, sendo substituído pelo turista. 0 autor propõe que a prioridade absoluta seja dada ao habitante, sem que, no entanto, se promova a exclusão de ninguém, muito menos do turista, e completa: "supõe-se que o que é bom para o turista tem necessariamente que ser bom, antes, para o habitante" (Meneses, 2004a, p. 259). Nesse sentido, a implantação de museus que estejam em consonância com a cultura, os desejos e a vocação da população da cidade se torna essencial, para se evitar uma dominação simbólica do espaço a ser revitalizado. "Projetos que não tenham legitimidade local ou que venham a meramente reproduzir modismos importados tendem a ter um efeito negativo sobre a identidade local", evidenciando um retrocesso na mudança proporcionada pela percepção da função social dos museus (Amazonas e Lima, 2010, p. 101).

Ainda que isoladamente os museus não sejam capazes de sustentar o desenvolvimento de uma localidade, verifica-se sua fundamental importância como potencial atrativo de investimentos e fluxos, assim como seu papel essencial como instrumento de valorização de uma identidade local.

\section{MAO como alavanca} para a revitalização da Praça da Estação

De fato, é a partir do projeto de implantação do MAO que a prefeitura da capital retoma um processo de recuperação da região, cujos desdobramentos reverberam em um processo mais amplo de revitalização de toda área central de Belo Horizonte. ${ }^{6}$ Tal processo se mostra em perfeita consonância com as tendências apontadas por diversos autores, (Falcão, 2003; Botelho, 2005; Barreira, 2010) de execução por parte do poder público, de estratégias que visam a recuperação e a adaptação das estruturas históricas dos centros das cidades com vistas à reversão de processos de degradação e à retomada de um papel hegemônico dessas regiões. 0 que se daria efetivamente a partir de uma perspectiva de incremento das atividades turísticas e culturais.

Como nos é apontado em documento presente no banco de experiências do Ministério das Cidades, esse plano de requalificação do centro de Belo Horizonte teria como um de seus objetivos:

incorporar todos os agentes sociais da cidade dentro de uma perspectiva de tornar Belo Horizonte um grande centro de produção e consumo de cultura, resgatando uma dívida que a capital tem com os mineiros de não ser ainda um espaço representativo e seminal para a cultura de Minas como foi Ouro Preto. (Brasil, Ministério das Cidades, 2007) 
Figura 1 - Primeiro prédio da Estação Central do Brasil, na Praça da Estação (1905). Demolido no início da década de 1920

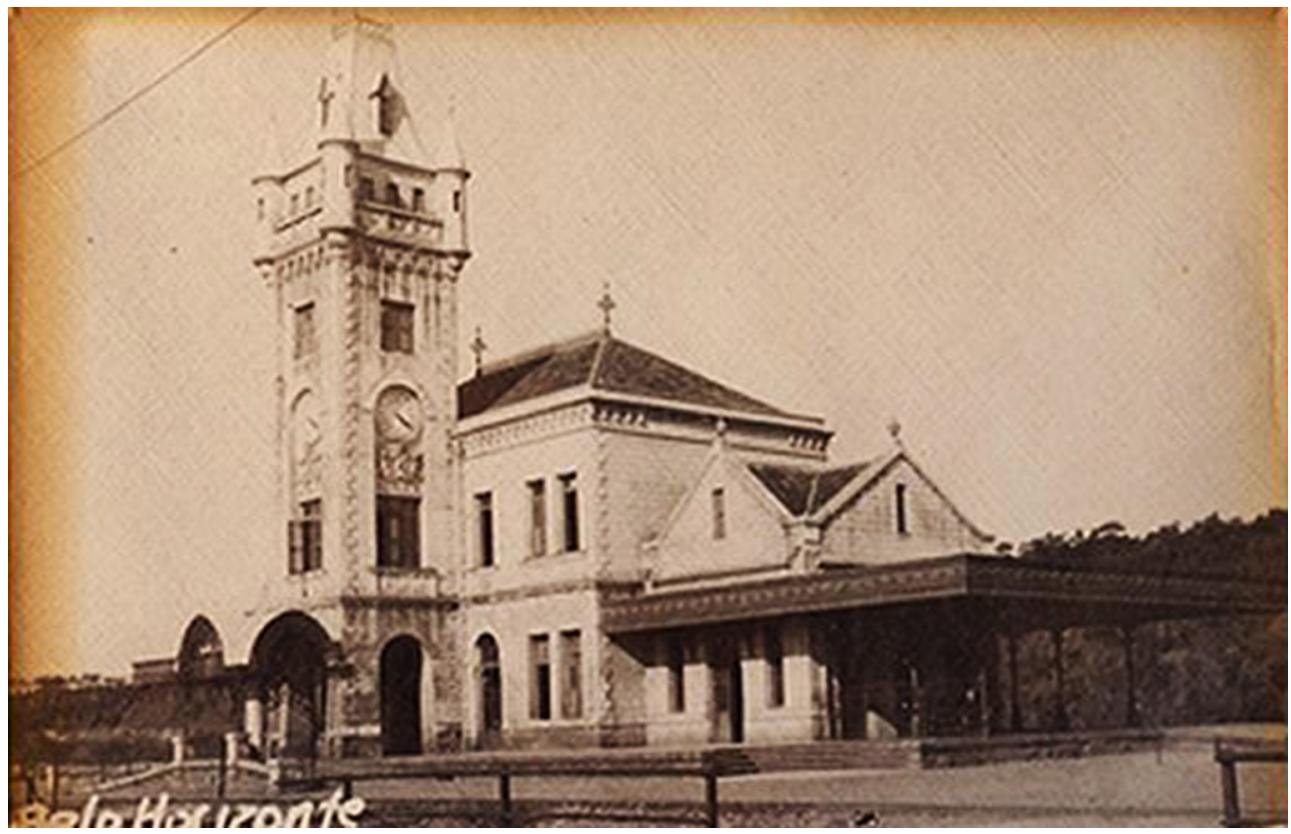

Fonte: Museu de Artes e Ofícios. Projeto Fio da Meada. Contando história: Praça Rui Barbosa - Estação. Belo Horizonte. A primeira década do século XX. Disponível em: http://www.mao.org.br/fiodameada/praca/pop.html).

Com base nesse trecho, nota-se claramente a elaboração de um discurso para a cidade que passa a ser pensada não mais apenas como um local de produção, mas como um produto de consumo, uma mercadoria. Se enquadrando perfeitamente nas características observadas em intervenções urbanas, apontadas por Vargas e Castilho (2006), na chamada fase de Reinvenção Urbana. Ainda com relação a tal plano percebe-se nele o papel fundamental do processo de recuperação da Praça da Estação na medida em que essa é apontada como "único espaço livre no centro da cidade, capaz de sediar grandes eventos públicos - festas, comícios, shows, representações teatrais -", sendo considerada ainda como "área prioritária de requalificação do espaço urbano". Cabe por fim mencionar o apontamento da implantação do MAO como possibilidade de se tornar "um dos lugares mais visitados de Belo Horizonte" (Brasil, Ministério das Cidades, 2007).

Tal compromisso do Museu como alavanca para o processo de recuperação e revitalização da Praça Estação pode ser evidenciado em um discurso da própria instituição desde sua concepção. Como pode ser observado nos anais dos Seminários de Capacitação Museológica, a "Requalificação do espaço urbano: os desafios impostos pela edificação e seu entorno" constam como um dos quatro eixos de seu 
projeto museológico (ICFG, 2004, p. 19). Nesse sentido, são retomadas várias vezes durante 0 documento a "importância do papel a ser cumprido pelo museu como instrumento de requalificação de uma área urbana que, apesar de sua importância histórico-cultural para a população de Minas Gerais, está completamente degradada" (ICFG, 2004, p. 20), da mesma forma levanta-se a "importância dessa ação de recuperação do espaço da Praça da Estação para fruição da população não apenas da capital mineira, mas de todo o país" (ICFG, 2004, p. 20). Ainda nesae sentido, cita-se como imprescindível que se estabeleça um cronograma de obras e compromissos com os diversos órgãos da Prefeitura de Belo Horizonte, "para o tratamento do entorno da edificação" (ICFG, 2004, p. 22).
Manifesta-se também a intenção do museu de "firmar parcerias com outros projetos da prefeitura voltados para a requalificação da vida urbana de Belo Horizonte" (ICFG, 2004, p. 24).

Dessa forma, torna-se clara a intenção de que a partir da implantação desse espaço museológico se retomasse um antigo projeto de revitalização urbana que tem uma longa trajetória, que remonta aos movimentos sociais em defesa da região na década de 1980, passando pelas sucessivas tentativas de recuperação na década de 1990, mas que não saíram do papel. 0 MAO, ao ser implantado nos edifícios da Estação Central, passava a representar uma oportunidade inédita de requalificação arquitetônica e de revitalização sociocultural da área que os circunda (Franco, 2004). ${ }^{7}$

Figura 2 - Vista do prédio da Estação, a partir do eixo da antiga Av. do Comércio (hoje Av. Santos Dumont). Inaugurado em 1922

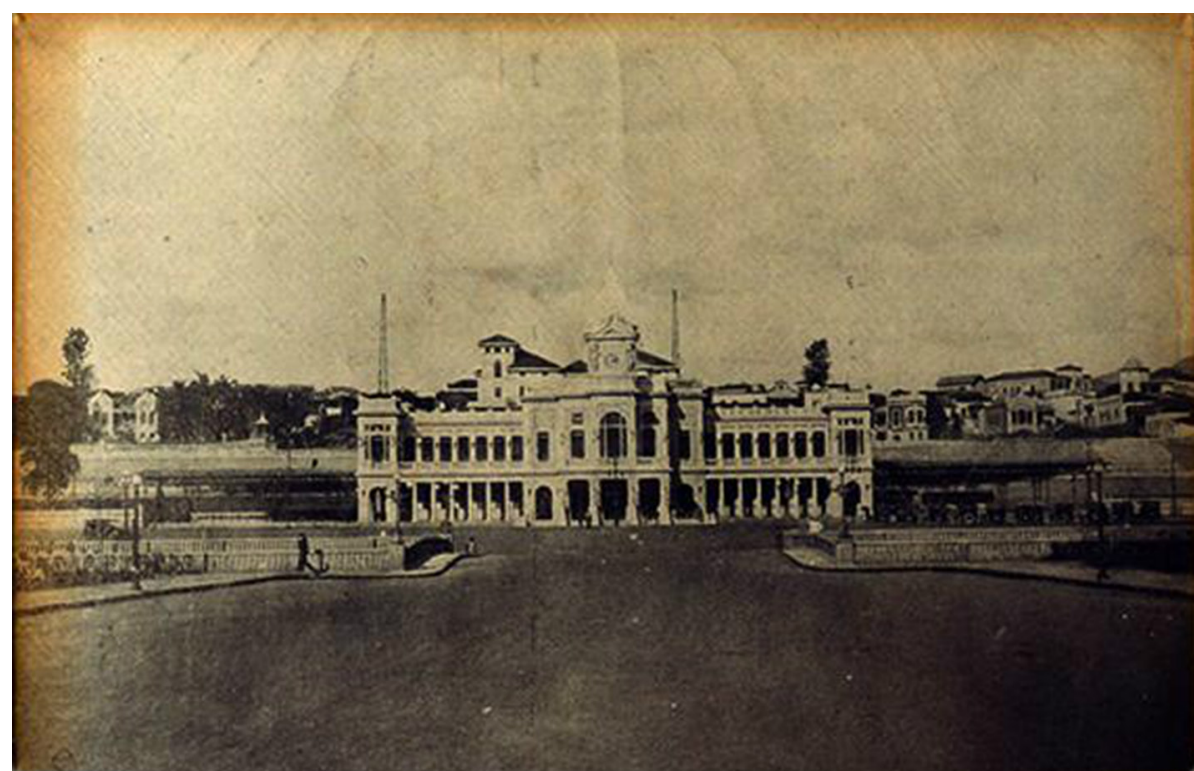

Fonte: Museu de Artes e Ofícios. Projeto Fio da Meada. Contando história: Praça Rui Barbosa - Estação. Belo Horizonte. Década de 1920. Disponível em: http://www.mao.org.br/fiodameada/praca/pop.html 
Sem adentrar no mérito das modificações físicas do espaço em si, o processo de revitalização associado à implantação do Museu permitiu a reversão de um processo claro de degradação do espaço. No entanto, é necessário explicitar aqui o que se está entendendo como "degradação" visto que essa é a principal justificativa para a necessidade dessas intervenções no espaço urbano. Vaz (2004a, p. 3) a caracteriza como uma "alteração no fluxo que se dirigia ao centro urbano. Alteração essa em termos de intensidade, natureza, receita e renda". Ainda tratando da questão da degradação, Barreira (2010) nos chama atenção para os conflitos simbólicos que se efetivam em torno do uso do espaço público, salientando que muitas vezes justifica-se a intervenção em nome de um esvaziamento destses espaços, 0 que, segundo a autora, revela-se na verdade como um ocultamento das chamadas "presenças indesejáveis".

A região da Praça da Estação encontrava-se em um processo de degradação, ocorrendo, nas proposições de Vaz (2004a), uma clara alteração nos fluxos que se dirigiam à região. Transformava-se, de portão de entrada da capital, em estacionamento, oficina informal, abrigo para moradores de rua, lugar de passagem a ser evitado pela população local devido a sua imagem associada com roubos, assaltos, prostituição, sujeira, delinquência entre outros fatores. ${ }^{8} \mathrm{~A}$ implantação do museu e o processo de revitalização se colocam como essenciais para reversão deste contexto de degradação, na medida em que, além de recuperar fisicamente o ambiente (ainda que em uma determinada proposta e discurso), torna-se capaz de reverter também essa imagem. ${ }^{9}$

\section{MAO entre a segregação} e a inclusão

Neste momento, cabe mencionar a questão dos conflitos simbólicos que se efetivam em torno dos usos do espaço público. Conforme colocado por Barreira é necessário não se esquecer dos ocultamentos das presenças indesejáveis que se configuram também como uma das justificativas e consequências da execução de processos de revitalização (2010). Faz-se necessário levar em consideração a multiplicidade de relações e sentidos que se efetivam no espaço urbano, incluindo aqui mesmo aqueles "à margem dos processos culturais, sociais e políticos hegemônicos e que são na maioria das vezes desconsiderados por serem banais e fragmentados" (Campici et al., 2006, p. 2).

Dessa forma, chega-se a uma das questões essenciais a serem observadas quando da análise de processos de revitalização urbana, a ocorrência do processo de gentrificação. No presente caso, por não se tratar de área com forte sentido residencial e relembrando os apontamentos de Botelho, a revitalização provocou uma modificação dos usos, mas não modificou o padrão residencial das áreas afetadas, portanto consideraremos como foco das análises as questões relativas à gentrificação de consumo e frequência (2005).

Com relação à circulação pela Praça, nota-se claramente o aumento do policiamento pela Guarda Municipal, o que pode contribuir na coibição de crimes e atos vandálicos, porém tal coibição não se reflete no direito de ir e vir à Praça da Estação. Por ela circulam diariamente moradores de rua, trabalhadores, famílias, casais de namorados e crianças. Da mesma 
forma, a Praça acolhe eventos de caráter variado, a maioria de grande concentração popular como shows, manifestações civis, celebrações festivas e religiosas. Portanto não se vê, a priori, um processo claro de segregação e elitização do espaço. No entanto, fazem-se necessárias algumas observações. Conforme nos aponta Giffoni, o Plano de Reabilitação do Hipercentro de Belo Horizonte, datado de maio de 2007, nos demonstra, em uma síntese da dinâmica urbana, que a maior apropriação existente na área do Conjunto Arquitetônico e Paisagístico da Praça da Estação é da população de rua. Em cima dessa constatação, a autora pontua que "as propostas existentes para o lugar não validam esse uso e não apontam alternativas para esse público, o que pode caracterizar um processo de gentrification no local" (2011, p. 6). Sem que seja proposta aqui uma abordagem de vitimização do indivíduo é preciso que sejam implementadas ações que busquem uma integração dessas pessoas à nova dinâmica social e econômica do lugar, compreendendo a questão da população de rua como uma situação que perpassa por questões sociais mais profundas. Nesse sentido, faz-se necessário propor ações de valorização e apropriação de maneira plural e inclusiva (Giffoni, 2011).

A praça também já se transformou em centro de conflito. Em janeiro de 2010, a prefeitura de Belo Horizonte decretou a proibição de eventos de qualquer natureza nesse espaço (Decreto n. 13798). Tal ação justificava-se pelas dificuldades de se limitar o número de pessoas e de garantir a segurança pública no local devido à aglomeração, bem como as depredações ocorridas ao patrimônio público em decorrência dos eventos realizados na Praça. Sem julgar a pertinência ou não de tal instrumento, o fato é que ocorria uma falta de dimensionamento e consequentemente de controle de tais eventos. No entanto, tal proposição (a de se proibir eventos de qualquer natureza) acabou gerando grande movimentação por parte da sociedade civil, o que acabou culminando em sua revisão por parte da prefeitura. Dessa forma, em setembro de 2011 ocorre a publicação da chamada "Lei da Praça Livre" (Lei n. 10277), que dispõe sobre a realização de atividades artísticas e culturais em praça pública no município.

0 que cabe destacar aqui é a ocorrência clara de um processo de gentrificação do espaço, induzido pela administração municipal, que repercutiu de maneira negativa inclusive para o MAO. Isso se devendo principalmente ao fato que o MAO passou a ser identificado como a sede principal da Praça por parte de alguns habitantes, que direcionaram suas críticas à sua administração. ${ }^{10}$ Faz-se necessário entender que há um conflito entre o projeto da Praça da Estação como um espaço para a realização de grandes eventos e o novo uso dos prédios como museu. Tal conflito pode ser verificado em entrevista realizada por Sales, com a coordenação em Museologia do Museu (Sales, 2010).

Outra observação que se faz necessária, a respeito da ocorrência de um processo de gentrificação no contexto aqui analisado, está relacionada à natureza do próprio MAO como museu e à realidade dos museus brasileiros. Como visto anteriormente, o processo de implantação do MAO é herdeiro de uma época em que já se discute amplamente a necessidade dos museus de terem uma função crítica e transformadora da realidade social. Com a quebra de um paradigma dos museus como lugares associados exclusivamente ao universo 
simbólico das elites e a uma ideia hierarquizada de cultura, bem como de um alargamento da noção de patrimônio (Choay, 2001; Julião, 2006; Mattos, 2010). Questões essas que se rebatem, por exemplo, na natureza do acervo do Museu e na temática a qual esse se dedica, artefatos do século XVIII ao XX relacionados ao universo do trabalho pré-industrial no país e o trabalho como herança patrimonial respectivamente. Além disso, os próprios edifícios que o Museu ocupa se constituem como testemunhos da era industrial, que passam a ser considerados patrimônio a partir das mesmas questões. No entanto, como confirmaremos a partir dos dados de alguns pesquisadores (Cougo, 2007; Corrêa, 2010), ainda com todos os esforços engendrados no sentido de uma maior participação popular nos museus, tanto nas questões relativas às suas representações nesses espaços (Cunha, 2012), como de sua frequência a essas instituições, os museus brasileiros ainda são lugares visitados em sua maioria por camadas representantes das elites sociais. E nesse quesito o MAO não constitui exceção. ${ }^{11}$ Nesse sentido, pode-se perceber, no presente caso, uma conformidade com os apontamentos de Queirós (2007), para o qual a implantação de instituições culturais em estratégias de revitalização urbana acaba por inevitavelmente resultar em um processo de gentrificação. Pois tais instituições são capazes de atrair um certo tipo de pessoas, pessoas essas pertencentes ao grupo que mais consome cultura.

Sobre a capacidade do MAO de atuar no seu entorno produzindo um "distrito cultural" (Vaz, 2004b), 12 já se evidenciavam a recuperação do centro histórico da cidade e a possibilidade de transformação da região em um polo cultural, com o Museu atuando como mola propulsora do processo. Desse modo, retomando o conceito de Vaz, no qual o distrito cultural se caracterizaria como uma "área espacialmente distinta e limitada que contém alta concentração de ofertas culturais" tanto em termos de consumo como de produção (2004b, p. 233). ${ }^{13}$

0 oficialmente denominado "Conjunto Paisagístico e Arquitetônico da Praça Rui Barbosa" ${ }^{14}$ compreende uma série de edificações localizadas em território no centro de Belo Horizonte, atravessado pelo Córrego Arrudas e delimitado a norte e a sul pelos viadutos da Floresta e Santa Tereza. Nessa faixa de território localizada na região central da cidade podem ser encontradas uma multiplicidade de iniciativas que se agregam de maneira induzida, através de investidores privados e do planejamento estatal como, por exemplo, a Sede da Superintendência do IPHAN e a representação regional da Funarte, instaladas na antiga Casa do Conde de Santa Marinha, e a Serraria Souza Pinto, que funciona como centro cultural recebendo eventos de natureza diversa. Há também instituições e movimentos que se agregam de maneira espontânea, não induzida, a partir de pessoas ou de grupos informais de produtores culturais, caso do Duelo de MCs e das ocupações de diversos movimentos como o Praia da Estação, que ocorrem nos espaços do viaduto Santa Tereza e na Praça da Estação. Além das instituições e atividades já consolidadas no espaço, existe o projeto de criação oficial de um corredor de instituições culturais nomeado Corredor Cultural Estação das Artes. Uma proposta da Fundação Municipal de Cultura - FMC, que será executada com recursos do Programa de Aceleração do Crescimento - PAC das Cidades 
Históricas, com vistas a uma nova requalificação dos espaços incluindo "melhoria dos passeios, iluminação e a sinalizacão dos nrédios e monumentos, hospedaria, na Escola Livre de a execução do tamento pela $\mathrm{F}$ mais de 20 equi à área cultural.

A partir d e propostas, fic de um distrito $c$ do Museu e do Praça Rui Barbo

\section{MAO entre 0 espetáculo e o fórum}

Quando utilizados em processos de revitalização urbana, verificam-se duas tendências que podem se amalgamar, o museu como atrativo turístico, e o museu como instrumento de desenvolvimento local.

Implantado a partir de uma iniciativa do ICFG, em parceria com o Ministério da Cultura e a CBTU, portanto fruto de uma parceria entre o setor público e a iniciativa privada, 0 MAO quando analisado em conjunto com o processo de revitalização da Praça da Estação e, em sentido mais amplo, com o programa de ações de requalificação do centro da cidade (Centro Vivo), com a ampliação das vias de circulação da região (Boulevard Arrudas), com o sistema de transporte rápido por ônibus (BRT) e com a sua ligação estratégica ao Aeroporto Internacional de Confins (Linha Verde), parece acompanhar as tendências observadas ao redor do globo, de utilização de estratégias de marketina urbano baseadas em intervencões 
Figura 3 - Vista Parcial dos Jardins e dos edifícios da Praça em 1954

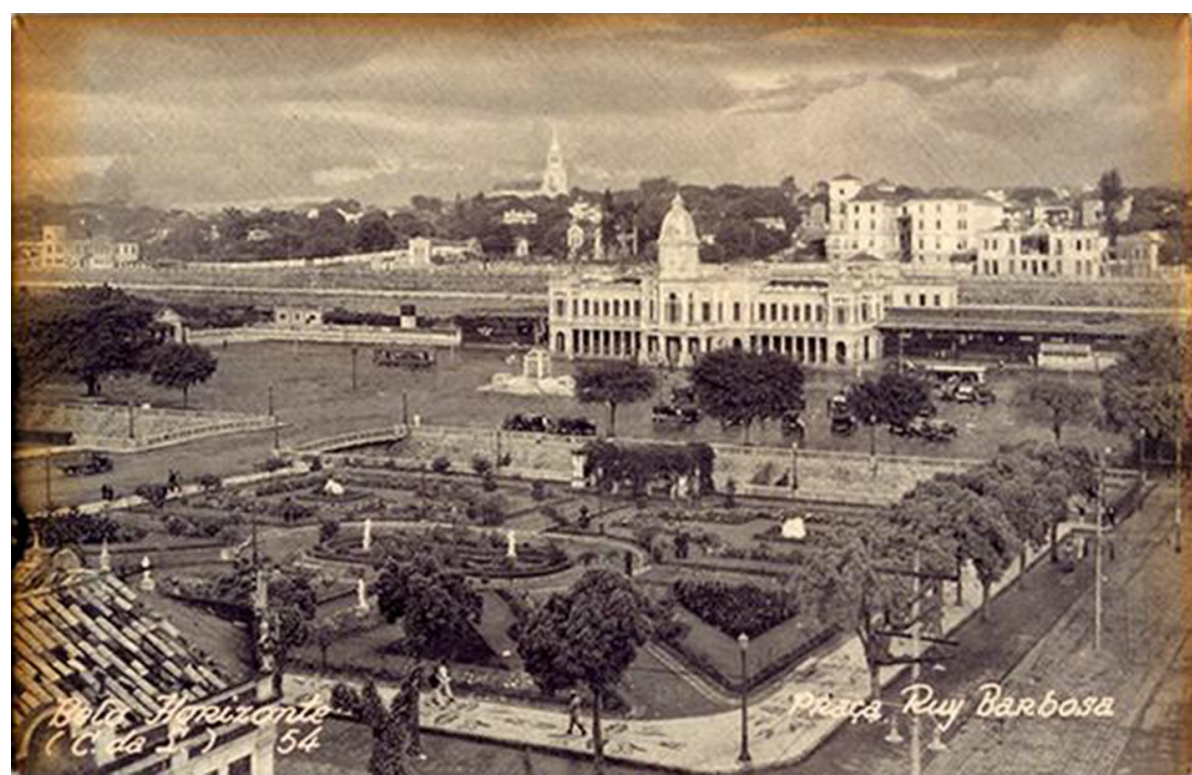

Fonte: Museu de Artes e Ofícios. Projeto Fio da Meada. Contando história: Praça Rui Barbosa - Estação. Belo Horizonte. Década de 1930. Disponível em: http://www.mao.org.br/fiodameada/praca/pop.html

Somadas as transformações em grande escala ocorridas no espaço, tal cenário poderia, conforme enunciado por Jacques, apontar para a ocorrência de um processo de "mercantilização espetacular da cidade" (2004), no qual as estratégias de marketing urbano e turismo lançariam essa imagem espetacular da urbe em uma competição internacional do mercado de cidades turísticas, que se dá principalmente através de atrativos culturais. No entanto, ainda que o MAO seja identificado como o principal gerador de fluxo turístico para o local (Murta, 2008; Giffoni, 2010; Corrêa, 2010), ele está longe de promover tal espetacularização. As razões para tanto estão contidas na própria forma com que o Museu vem atuando na sociedade, na apropriação por parte da sociedade dos espaços revitalizados e, por fim, em um descompasso das instâncias governamentais na potencialização de um turismo cultural na capital. Murta (2008) e Giffoni (2010), em trabalhos de pesquisa a respeito do potencial turístico da região da Praça da Estação, identificam de maneira semelhante uma presença incipiente do turismo no espaço. Verifica-se a existência de planos de potencialização turística nas três esferas de governo, com metas quantificadas para o setor turístico, mas tais planos se apresentam de maneira genérica e não indicam ações de retroalimentação do sistema, que levem o turista ao atrativo (Giffoni, 2010). Identifica-se que, apesar de pesquisas feitas pela Fundação Getúlio Vargas (FGV) em parceria com o Ministério do Turismo apontarem que 
os principais atrativos do destino turístico Belo Horizonte se caracterizam na visão do turista nacional em $50 \%$ e na do turista estrangeiro em $48 \%$ pela oferta de turismo cultural, há um descompasso entre a identidade/imagem turística que se pretende estabelecer para a cidade pelo governo estadual (turismo de negócios) e pela municipalidade (turismo cultural). Sendo necessária uma integração entre as duas instâncias para uma ação conjunta que decida o destino turístico de Belo Horizonte (Giffoni, 2010, p. 60).

Ainda que se perceba uma visão da prefeitura municipal para um uso turístico do conjunto da Praça da Estação, identifica-se que esse uso turístico do espaço não se sobrepôs a seu uso cotidiano. Pelo contrário há uma apropriação por parte da sociedade na qual se vislumbra uma presença marcante no cotidiano da região pela população local. "A Praça da Estação, sustentada por sua história, inserida no cotidiano da população residente e transformada para acolher visitantes, não se fez exclusivamente para o turismo, mas se apresenta agora também para ele" (Murta, 2008, p. 130). Esses apontamentos vão de encontro ao proposto por Meneses, para o qual, na inserção da cultura como capital para projetos de revitalização urbana, toda a prioridade deve ser dada ao habitante, sem, no entanto, promover uma exclusão do turista (2004b). Ainda segundo o autor, o habitante relaciona-se de forma intensa, contínua, constante, atingindo níveis muito abaixo da superfície das aparências. Já o turista, por mais que sua disposição seja grande e generosa, não conta "com os efeitos cumulativos da habitualidade, da continuidade, do acréscimo de valor que a experiência cotidiana e a memória podem gerar pouco a pouco". "A falta de integração numa trama da vida reduz a fruição ou a concentra predominantemente na dimensão visual". Dessa forma, é preciso estar atento para a inversão de prioridades que o chamado "turismo cultural" pode acarretar (Meneses, 2004b, p. 202).

0 que é feito para a cidade pode com certeza ser aproveitado para o turismo, boas exposições, bons projetos, espaços agradáveis que a população frequente. " 0 turista se sente seguro ao perceber que a população circula pelos espaços que ele visita. Espaços apropriados pela população atraem usos que são interessantes também para o turista" (Murta, 2008, p. 99). Além disso, essa apropriação do espaço urbano por parte da população local vai de encontro ao postulado por Jacques, para quem a chave para reversão de processos de espetacularização do espaço estaria em uma efetiva participação da sociedade através dos usos e significados diversificados que essa imprime ao espaço público. Contribuindo para a construção de uma cidade como palco, transformando o cidadão em ator protagonista ao invés de mero espectador (2004).

Dessa forma, observa-se que não só na Praça da Estação, mas que no Conjunto Paisagístico e Arquitetônico da Praça Rui Barbosa como um todo, diversos atores sociais conseguem reverter um possível processo de gentrificação no espaço ao se apropriarem do mesmo, seja para encontros ou eventos variados. Iniciativas como o Duelo de MCs, o Quarteirão Eletrônico, Praia da Estação e os movimentos de ocupação nos dão prova disto. 
Se a Praça da Estação era apenas um corredor de passagem, nela hoje há uma integração que provoca um processo de inclusão muito interessante, um compartilhamento do espaço público por grupos diferenciados. Isso constitui um ponto positivo em um processo de revitalização de área, em que normalmente acontece o contrário, havendo a exclusão dos frequentadores originais. (Murta, 2008, p. 106)

Ainda nos resta por fim abordar como a atuação do MAO tem contribuído para a inclusão efetiva desse morador. Adentramos, portanto, nas postulações sugeridas por Queirós, para o qual espaços de cultura implantados, anteriormente ou a partir de processos de revitalização urbana, teriam um papel fundamental a desempenhar nesses processos, a partir de sua atuação e integração com a realidade social local (2007).

Não há dúvida de que o MAO é uma instituição que incorpora em sua proposta um conceito contemporâneo de museu. Dessa maneira, podemos encontrar em suas instalações uma linguagem expositiva que faz uso de recursos tecnológicos e multimeios, como projeções de vídeo, ambientação sonora e conteúdo extra, disponibilizados em multimídias. Sua proposta museográfica, executada pela Panoptès Muséographie e assinada pelo museógrafo francês Pierre Catel, propõe uma integração museu/estação de modo a fazer com que "o usuário do metrô se perceba imediatamente, sob os mais diferentes pontos de vista, dentro de um museu" (IGFG, 2004, p. 28). Além disso, o Museu conta com espaços de consumo como o Café dos Ofícios, sua loja e ainda dispõe de espaços alternativos para realização de eventos culturais, empresariais e sociais, identificados como demandas de uma indústria cultural.

0 que inicialmente poderia apontar para a existência de um "museu-espetáculo", 16 acaba, no entanto, nos demonstrando em um olhar mais aprofundado que a escolha dessas linguagens no Museu se dá de maneira bastante acertada. Em um primeiro momento com relação à proposta museográfica executada, houve de fato uma valorização do edifício com a presença de algumas estruturas adaptadas, que, no entanto, não promovem uma descaracterização do mesmo. Os prédios das estações Central do Brasil e Oeste de Minas se destacam na paisagem urbana sem que se sobressaiam intervenções e acréscimos contemporâneos.

0 uso de tecnologias no Museu se dá como complementação da linguagem expositiva, de modo a permitir que no MAO se façam presentes diferentes ritmos de visita. Em nenhum momento tal recurso se sobressai sobre os artefatos expostos na instituição. São eles (os artefatos) que se destacam todo tempo, articulados conforme os enfoques temáticos do Museu.

Quanto à presença dos espaços de consumo no MAO, faço aqui duas observações. A primeira vem da necessidade de percepção dos museus como fenômenos sociais, que "estão intrinsecamente relacionados às sociedades que os geram" (Abreu, 2012, p. 11); nessa medida estão "permanentemente se transformando e se adequando a demandas sociais" (Abreu, 2012, p. 12). A segunda observação se apresenta na forma de uma breve colocação de Meneses para o qual "nesta ótica, valor cultural e valor econômico não são contraditórios e muito menos excludentes. Contraditórias, sim, e excludentes são as lógicas culturais e as de 
Figura 4 - Vista da fachada do Prédio da Estação Central de Belo Horizonte - Sede do MAO

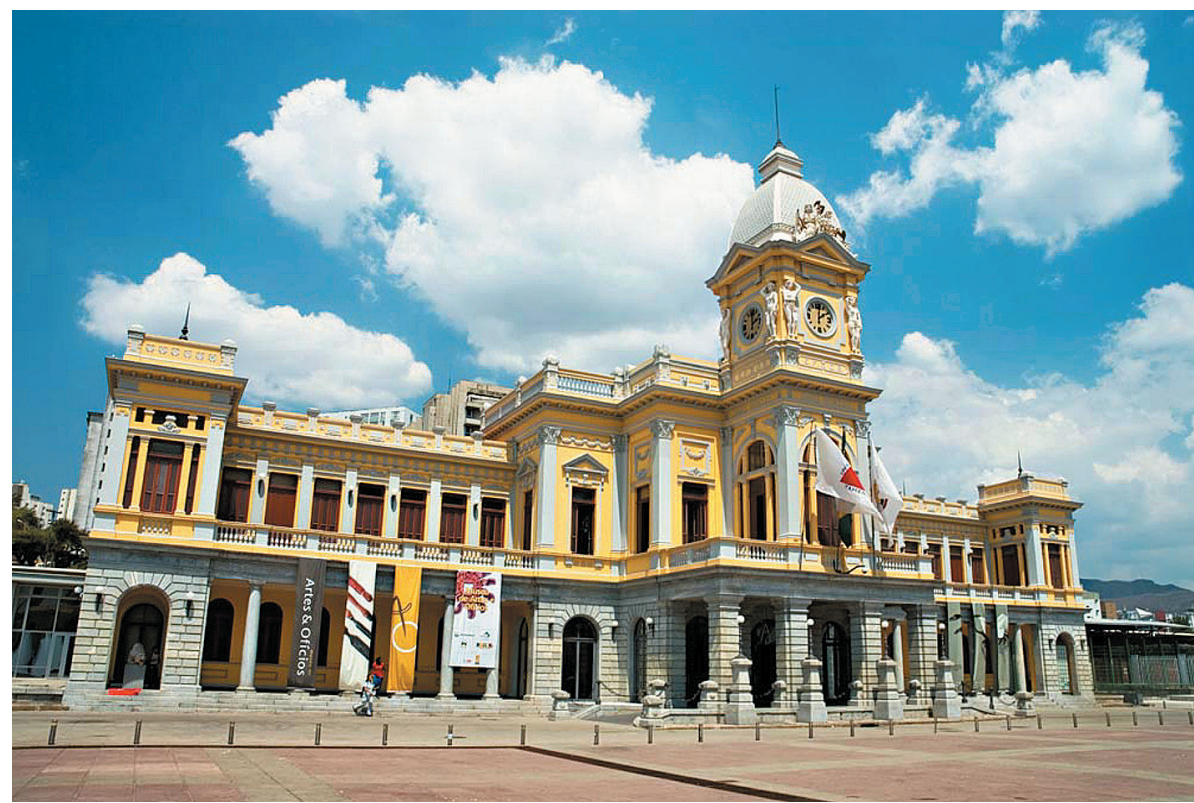

Fonte: Divulgação Belotur. Guia das Sedes da Copa do Mundo: Brasil 2014. Disponível em: http://www.copa2014.turismo.gov.br/export/sites/default/copa/guia_sedes/Belo_Horizonte/imagens_bh

mercado" (2004a, p. 269). 0 que quero apontar com tais observações é que, se o Museu oferece tais espaços para consumo, sua existência se justifica a partir da identificação de uma demanda social para tal. Ainda que os artefatos nele presentes não se encontrem mais nesse contexto, não se deve retirar o espaço do museu do mundo cotidiano, do ciclo da vida. É preciso incentivar novas formas de apropriação do Museu desde que essas não coloquem em risco o patrimônio sob guarda da instituição e que as mesmas não resultem em um conflito no cumprimento de sua missão e função social. Portanto, se há demanda para se realizar reuniões, palestras ou festas no MAO considero favorável que ele seja utilizado dessa forma.
Ainda que colocadas todas as observações acima, o motivo primordial pelo qual o MAO não se constitui como um espaço espetacularizado reside no fato de que, em sua percepção, o fluxo de visitantes está fundamentalmente centrado no cidadão local como o principal usuário do Museu. Tal acontecimento não se dá de maneira gratuita, é antes de tudo uma mentalidade institucional, para a qual contribuem alguns fatores presentes na gênese da instituição.

Neste momento, coloco em destaque aqui as discussões a respeito da função social dos museus a partir da década de 1970 e de como tais discussões evidenciam novos modelos de relacionamento museu/sociedade a 
partir da consolidação do conceito de Ecomuseu e museu comunitário e do estabelecimento de um movimento por uma Nova Museologia.

A partir dessa constatação, veremos como os desdobramentos desses conceitos atuarão de maneira decisiva no estabelecimento dessa visão por parte do MAO. Em primeiro lugar estão o próprio processo de implantação do Museu e a forma como esse foi conduzido. 0 estabelecimento de três seminários dedicados à apresentação e ao debate dos princípios e metodologias de trabalho que se consolidariam na implantação do futuro museu. ${ }^{17}$ Antes que o Museu existisse de fato, o mesmo se abria para ser debatido em sociedade. Nesse quesito, o MAO se destaca propondo uma ação pioneira no universo dos museus brasileiros. Uma informação essencial ainda com relação a esse momento de discussão do novo museu foi a elaboração de um Banco de Ideias que reuniu questões e sugestões de aspectos a serem considerados no processo de implantação do MAO, "ideias estas que foram e estão sendo, em sua maioria, incorporadas ao projeto do museu", segundo nos aponta os Anais desses seminários (ICFG, 2004, p. 15).

Destacam-se a constatação da importância que o MAO, desde sua concepção, conte "com um plano estratégico de comunicação, de modo a torná-lo presente entre a população mesmo antes de sua inauguração" (ICFG, 2004, p. 18), e a ideia de que o Museu se comportasse desde seu início (fato atestado pela própria natureza dos encontros), como "uma obra aberta, em processo, acolhendo conexões propostas pelos diversos atores sociais" (ICFG, 2004, p. 18).
Chamo atenção agora para o apontamento claro do conceito de ecomuseu como uma das fundamentais referências para o estabelecimento do MAO. Mais uma vez fazendo alusão ao documento dos Anais de Capacitação Museológica, nele explicita-se "os três tipos de museu - ecomuseus, museus de ciência e técnica e museus de sociedade - tomados como referência para o conceito gerador" (ICFG, 2004, p. 19).

Franco, em exposição a respeito do programa museológico do MAO, menciona que o conceito gerador do Museu objetiva abordar o trabalho como herança patrimonial. Dessa forma, a mesma pontua:

Esse conceito gerador foi inspirado em elementos constitutivos dos museus de sociedade, ecomuseus, museus de técnica, pois estes evidenciam diferentes diretrizes para o tratamento do patrimônio vinculado ao trabalho, como resultado das relações que se estabelecem entre os gestos e o domínio das técnicas, e são, também, modelos de musealização que privilegiam os ofícios e as artes. $(2004$, p. 40$)$

Influenciado por esses novos modelos de musealização, o MAO deveria cumprir o desafio de ser "um museu que sensibilize e integre 0 transeunte cotidiano da região e nele desperte uma nova interlocução relativa às questões intrínsecas ao universo do trabalho no Brasil" (Franco, 2004, p. 40). Destaca-se então uma visão diferenciada por parte da instituição de estabelecer um relacionamento com o território abordado e da necessidade de ser dada prioridade ao habitante local na apropriação do espaço museológico, convidando a sociedade a uma construção conjunta do Museu. 
Necessidade apontada pela idealizadora do projeto:

Mais do que um museu para a cidade, este é um museu com a cidade. Aberto à opinião pública, ao diálogo, à troca de ideias. Pela forma como temos conduzido a sua implantação, o Museu de Artes e Ofícios tem se caracterizado como uma das mais dinâmicas e transparentes experiências de realização de um projeto cultural desta envergadura. (Gutierrez, 2004, p. 34)

Por fim, cito aqui entrevista realizada com o responsável pelo projeto museográfico do Museu na qual define claramente a vocação da instituição como pensada para um público local e, prioritariamente, para uma parcela especial desse público local. ${ }^{18}$ Tais prioridades estabelecidas durante o processo de implantação do Museu se desdobram nas atividades realizadas pelo MAO hoje. Além de restaurar um bem cultural com presença marcante na identidade belo-horizontina, o Museu apresenta artefatos que se identificam com o imaginário local em sua exposição. Além disso, o MAO se coloca como uma presença ativa na sociedade em que se insere através de seu amplo programa educativo e dos programas sociais que utilizam o espaço do Museu como laboratório, ${ }^{19}$ somadas a exposições temporárias que tratam de temáticas locais, ${ }^{20}$ tais ações contribuem para fazer do MAO um museu com profundas ligações com o tecido social no qual está inserido.

Figura 5 - Vista aérea da Praça Rui Barbosa após o processo de revitalização

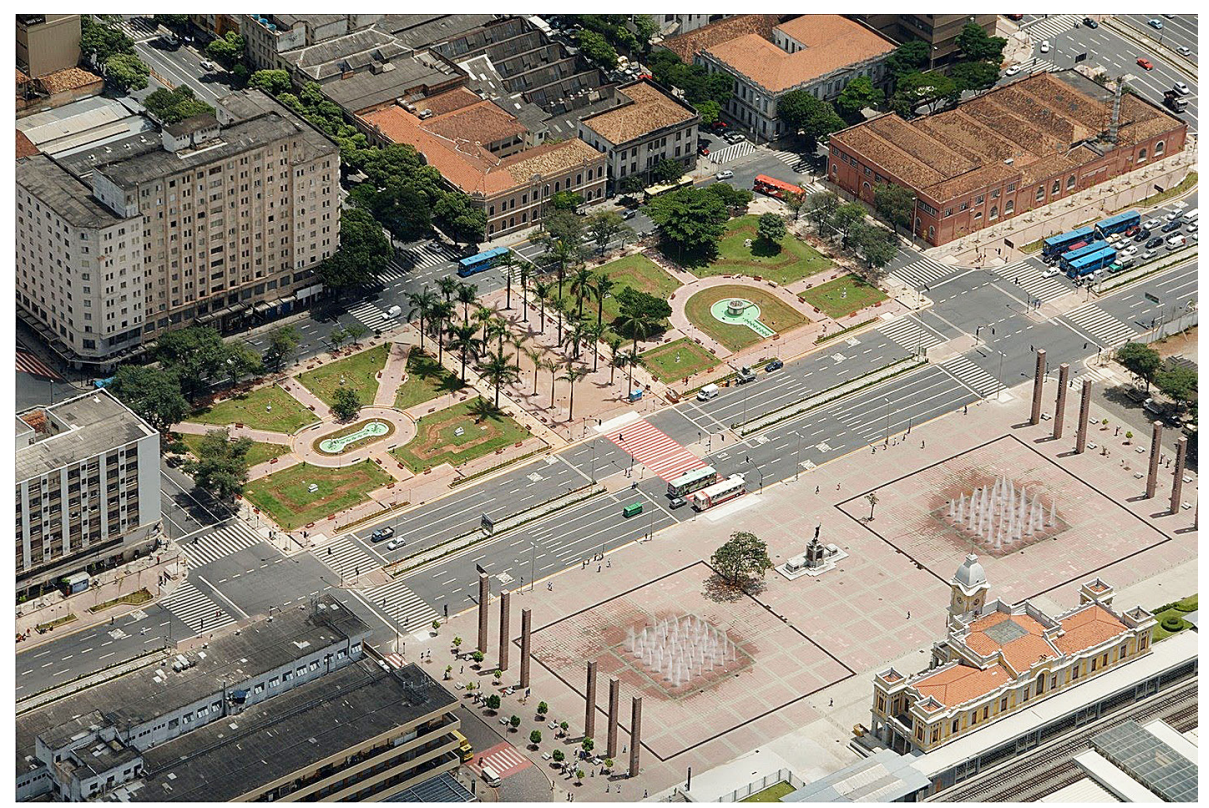

Fonte: B\&L Arquitetura. Disponível em: http://www.belarq.com.br/. 
Desta maneira observa-se, como nas proposições de Amazonas e Lima (2010), a existência de um museu que se configura ao mesmo tempo como um importante atrativo turístico e como um instrumento de desenvolvimento local, na medida em que leva em consideração essa cultura local e as relações sociais existentes, se destacando como um elemento central no processo de valorização e ocupação do espaço urbano.

\section{Considerações finais}

Os museus originam-se a partir de estratégias diferenciadas. Alguns nascem da reunião de grandes legados nacionais, outros da coleta científica sistemática; há aqueles que vêm à luz para defender determinados princípios e ideais de um determinado grupo social; muitos são constituídos para reafirmar contextos econômicos, sociais, étnicos e até mesmo políticos; outros cumprem uma missão de resgate de uma cultura em extinção; há ainda os que se dedicam a nos revelar 0 mundo natural, as experiências e as descobertas humanas. Um sem número de situações constitutivas norteia a geração de museus em todo o mundo, e a museologia tem se dedicado intensamente, nas últimas décadas, a analisar esses contextos, suas características, seus desafios e resultados. (Franco, 2004, p. 38)

Analisar o contexto, as características, bem como os desafios e resultados da implantação de museus em processos de revitalização urbana e, de maneira específica, da implantação do MAO na Praça da Estação, região central de Belo Horizonte, foi o objetivo principal do estudo aqui desenvolvido.
Como visto percebe-se que, quando utilizados como catalisadores em meio a esses processos, os museus apresentam a potencialidade de proporcionar uma ampliação dos benefícios sociais resultantes de tais iniciativas, desde que estejam em consonância com a cultura, os desejos e a vocação da população do território no qual se inserem. No entanto, para que se consolidem de tal forma, é necessário que se esteja atento a algumas armadilhas que se apresentam durante o percurso. Como observado, os processos de revitalização acabam sempre, em maior ou menor escala, resultando em um processo de gentrificação. Fator que, quando associado a uma possível espetacularização do espaço urbano, coloca o habitante à margem da fruição do local, na medida em que produzem espaços de consumo que visam ao turista, consumidor de lugares.

Na compreensão do papel que as instituições museológicas têm a desempenhar em meio às ações de ressignificação urbana, observa-se que os museus quando presentes em tais contextos têm um papel central, na medida em que poderiam acarretar uma reversão dos processos exclusórios de tais processos, transformando o espaço espetacularizado em fórum, um espaço privilegiado e participativo, inclusivo, no qual, ainda que a prioridade seja dada ao habitante local, não se exclui o turista do processo. Por outro lado, quando não vinculados às aspirações do tecido social no qual se inserem, resultam na produção de um efeito contrário, corroborando um processo de gentrificação do espaço, modificando os significados do patrimônio, transformando-o puramente em um segmento do mercado.

Verifica-se também que a sociedade local tem um papel fundamental, na medida 
em que, como cidadãos, deve se apropriar, de fato, para os mais diversos usos, dos espaços públicos. 0 que permitiria em última instância uma diversidade de significações e grupos sociais sendo representados na dinâmica urbana.

No que diz respeito à realidade em questão, verifica-se que a implantação do Museu, somada ao processo de revitalização da Praça da Estação, foi capaz de devolver uma região de grande simbolismo para a população belo-horizontina. A implantação do Museu nos edifícios da Estação Central representa a consolidação de um antigo desejo de que tais edificações assumissem vocações culturais, sendo então resultado de uma legítima demanda social.

0 projeto de adaptação das edificações não resultou na criação de um espaço espetacularizado, com o projeto de intervenção e restauro tendo respeitado a ambiência e a volumetria das edificações. 0 MAO consolida-se hoje como uma das principais instituições museológicas da capital e uma referência nacional pela forma com que foi implantada.

No entanto, alguns desafios permanecem. É necessário que o Museu procure estratégias que possam incorporar os diferentes grupos sociais de moradores da cidade, atingindo não somente aqueles que tradicionalmente já se caracterizam como um público visitante de museus. Tais ações deveriam objetivar uma inclusão que comece pelos grupos presentes no espaço em questão, com a intenção clara de que se rompa com o domínio do discurso.

Observa-se a necessidade de uma maior integração entre as diversas instituições e grupos sociais presentes nesse espaço, no sentido de se estabelecer um diálogo permanente entre as diferentes manifestações, de forma a consolidar o espaço de estudo como um polo cultural. Ações como o Duelo de MCs no Museu já se caracterizam como um primeiro passo da instituição na busca de uma interlocução nesse sentido. É preciso entender que o corredor cultural na Praça da Estação já existe, com toda sua riqueza, baseada na diversidade, trocas e conflitos.

Como observado, pela maneira com que foi conduzido, pelas características da região e pelos desdobramentos do processo, o primeiro processo de requalificação urbana da região, em consonância com o processo de implantação do MAO, não produziu um espaço de pura gentrificação e consumo cultural, se constituindo, pelo contrário, como um espaço fértil e auto-organizado, com uma multiplicidade de manifestações e grupos culturais.

É recorrente que práticas urbanas espontâneas e auto-organizadas tentem ser incorporadas ao planejamento estratégico oficial a posteriori. Faz-se necessário que o novo projeto de requalificação já previsto para a região, com o objetivo de implantar o já referido Circuito Cultural Estação das Artes, seja conduzido com bastante cuidado para que não se reproduzam práticas gentrificadoras do espaço urbano. Ainda que esse projeto conte com algumas vantagens como o estabelecimento de uma comissão de acompanhamento, composta por membros dos diferentes grupos que compartilham este espaço, o mesmo não se encontra livre de contestação (Cançado, 2013).

Por fim, cabe observar aqui a importância que o espaço em questão tenderá a assumir com a aproximação de um evento em grande escala como a realização de uma Copa do Mundo no Brasil. A Praça da Estação se constituirá como um espaço privilegiado na realização dos eventos característicos da 
Copa, já que Belo Horizonte se tornou uma de suas cidades-sede, e a Praça da Estação se caracteriza como único espaço aberto na região central capaz de receber eventos de maior porte. Geralmente tais acontecimentos tendem a assumir um caráter completamente espetacularizado. Torna-se fundamental que os diferentes grupos e instituições que participam da construção deste corredor cultural se mobilizem de maneira a demonstrar aquilo que se caracteriza como manifestação autêntica da cultura local, sem falsificações ou falseamentos, não permitindo que a apropriação por meio do poder público acabe por produzir um espaço esvaziado de sua essência, que, no presente caso, é por vezes conflituosa, mas é também de produção e intercâmbio cultural ricos.

\section{Felipe Eleutério Hoffman}

Universidade Federal de Minas Gerais, Programa de Pós-graduação em Arquitetura e Urbanismo. hoffmanfelipe@yahoo.com.br

\section{Notas}

(*) Este artigo é baseado na monografia de conclusão de curso do autor, intitulada "O papel dos museus em processos de revitalização urbana: o caso do Museu de Artes e Ofícios de Belo Horizonte" defendida em outubro de 2012 no curso de Museologia da Universidade Federal de Ouro Preto.

(1) No sentido utilizado pelo autor, museificação diria respeito à transformação da própria cidade em museu, e musealização seria a proliferação de museus nas cidades contemporâneas.

(2) Para uma visão mais introdutória a respeito da origem do museu e da história do movimento museológico ver: Julião (2006, pp. 19-32).

(3 Para uma boa introdução ao surgimento dos Ecomuseus ver: Mattos (2010). 
(4) Um exercício interessante neste sentido é efetuar uma pesquisa por imagens em qualquer um dos sites de buscas disponíveis na rede, pelo nome de alguma das grandes cidades do globo. A prevalência de museus, construções históricas, paisagens naturais ou espécimes característicos da fauna ou flora, relacionadas a essas cidades pode ser notada de forma clara.

A esse respeito, Boavida nos sinaliza que as imagens: "Podem mesmo alterar, no seu conjunto, o curso da sua história. Algumas cidades têm a si associadas uma imagem positiva e empreendedora, outras, pelo contrário, transportam uma carga negativa. Estas imagens negativas estão sobretudo relacionadas com desemprego, exclusão social, violência e criminalidade, poluição e degradação do espaço público. Já as cidades que têm a si agregadas imagens positivas devem-no geralmente a um bom ambiente urbano, justiça social, empreendedorismo, cultura, paz social, acessibilidades ou situação geográfica e natural favorável" (2010, p. 3).

Nesse sentido, são elencados como paradigmáticos os casos do Centro Georges Pompidou, de Paris, o Museu de Arte Contemporânea e o Centro de Cultura Contemporânea de Barcelona e o Museu Guggenheim de Bilbao. Sendo esse último talvez o caso mais polêmico e controverso de museus que se convertem em "novos monumentos das metrópoles" (Ohtake, 2000). No caso brasileiro, o Museu de Arte Contemporânea, de Niterói, se constitui como exemplo de museu que se converteu em forte ícone de uma cidade.

(5) Como exemplo representativo destes agrupamentos de museus podemos citar a chamada Museum Mile, situada na 5a - Avenida na ilha de Manhattan, Nova York. Uma zona de grande concentração de museus, nas quais se encontram alguns dos mais visitados do mundo. No caso brasileiro um recente exemplo encontra-se no Circuito Cultural da Praça da Liberdade, em Belo Horizonte. Essa iniciativa ainda em implantação, quando consolidada figurará como um dos maiores complexos de instituições culturais do país.

(6) A criação da Praça Rui Barbosa ou Praça da Estação, como é popularmente conhecida, coincide com a fundação da cidade de Belo Horizonte no final do século XIX. Espaço seminal da capital mineira, a Praça da Estação é marco tanto pelas edificações que ainda existem ao seu redor, quanto pelos diversos usos que essas acolheram ao longo dos anos. Esse espaço tem se caracterizado na atualidade por um grande número de atividades e instituições culturais.

(7) A este respeito Murta nos apresenta que: “Quando, em 2002, o prédio principal foi inaugurado após a restauração, a Praça era um grande estacionamento, com problemas de segurança e de iluminação. A visibilidade alcançada pelo prédio recém-restaurado desencadeou uma ampliação das prioridades do Programa Centro Vivo no que dizia respeito à esplanada da Praça da Estação. Os urbanistas da municipalidade começaram a perceber que a Praça completaria um corredor cultural juntamente com a Serraria Souza Pinto, a Casa do Conde de Santa Marinha e o Centro Cultural da UFMG, espaços culturais criados em edificações que foram preservadas, restauradas e que são significativas na história de Belo Horizonte. As intervenções na Praça também seriam relevantes para a criação de uma estação de ônibus de integração com o metrô mais adequada ao perfil da cidade e resultariam numa releitura visual da área" (2008, p. 88). 
(8) Tal quadro ainda se encontra na mente de parte da população refletindo inclusive como um aspecto negativo na relação museu-visitante. Como pôde ser verificado em pesquisa realizada por Corrêa, na qual um determinado morador da cidade assinala a questão da violência urbana, como um dos fatores capazes de influenciar negativamente a visita ao MAO. Nas palavras do entrevistado, "a Praça foi um lugar que abrigava crianças de rua, morador de rua, talvez isso possa, no imaginário, ser um dificultador para a pessoa vir ao museu" (2010, p. 62). Corroborando tal fato, em investigação realizada por Cougo a respeito do potencial turístico de alguns museus de Belo Horizonte, verifica-se o alto índice de entrevistados que assinalam o item violência urbana como um dos principais fatores que dificultariam a visita ao MAO (2007, p. 135).

(9) Recorrendo novamente aos dados levantados por Corrêa, para a qual se percebe uma a ideia de retomada do espaço como um recurso urbano de desenvolvimento e qualidade de vida. O que pode ser exemplificado com a colocação de um desses entrevistados, na qual este diz: "hoje mesmo eu fiquei na Praça, a gente tem notícias que a Praça tem a Guarda Municipal, está mais bem tratada. Teve uma época que era horrível passar por aqui, hoje eu não sinto isso" (2010, p. 65).

(10) Esta associação entre a gestão da Praça e o Museu nos é apontada por Corrêa:

"O fato de a instalação do museu ter sido a primeira etapa para a recuperação da Praça da Estação faz com que os moradores da cidade vejam o MAO como uma espécie de sede principal da Praça. Eles acreditam que a manutenção e gerência do espaço externo acontecem a partir do MAO, sendo que, na realidade, isso é responsabilidade da Prefeitura Municipal. Não é raro um cidadão entrar no museu e perguntar se não é possível ligar as fontes da Praça 'por um minutinho', porque ele vai se casar e quer tirar uma fotografia para o álbum de casamento" (2010, p. 65).

(11) Como nos apontam Cougo (2007, p. 125) e Corrêa (2010, p. 95), a grande maioria dos visitantes do MAO possui um alto nível de escolaridade, com uma média superior a $50 \%$ sendo possuidora de formação em nível superior completo. Da mesma forma no quesito renda domiciliar mensal, a média do público visitante do Museu tem renda superior a dois mil reais (Corrêa, 2010, p. 164 e Cougo, 2007, p. 126). Dessa forma nota-se que a maior parte dos visitantes do MAO "possui uma situação econômica bastante confortável, em comparação com a média da população brasileira" (Corrêa, 2010, p. 164). Nessa ligação escolaridade, renda e visitação a museus, nota-se uma relação diretamente proporcional. Quanto maior a escolaridade, maior é a renda e maior a frequência de visitas aos museus (Bourdieu e Darbel, 2003).

(12) “A grande moldura do MAO é a Praça da Estação, homenageada nesta primeira exposição temporária. A sua completa recuperação é parte do projeto e sinaliza para a requalificação de todo o centro histórico da cidade, já definido como polo cultural, capaz de incrementar o turismo e outras atividades. O MAO quer ser a mola propulsora dessas transformações. E quer ser mais: um motivo de orgulho para todos os que amam Belo Horizonte" (MAO, 2002).

(13) Percebe-se que nas áreas adjacentes ao Museu, principalmente no chamado conjunto Arquitetônico da Praça da Estação, foram consolidadas ou instaladas instituições ligadas principalmente à divulgação, consumo e produção cultural e a preservação do patrimônio. Tal conjunto é inclusive abordado pelas ações educativas do Museu, como pode ser conferido em um mapa disponibilizado pelo setor educativo, no qual se destacam as instituições do conjunto da Praça da Estação apresentado no material como "um dos maiores tesouros da cidade". 
(14) Conforme lista de Relação de Bens Protegidos em Minas Gerais, disponibilizada pelo IEPHA/MG. Disponível em: www.mp.mg.gov.br/portal/public/interno/arquivo/id/3156 Acesso em: 15 jun 2012.

(15) Como nos aponta Corrêa em seus trabalhos de investigação: “(...) pôde-se perceber que a primeira fase da Praça da Estação se faz presente ainda hoje na relação entre os moradores de $\mathrm{BH}$ e o MAO. Pois, alguns deles chegaram à cidade por trem e, portanto, os edifícios da Estação Central e da Estação Oeste de Minas fazem parte de sua própria história, como lugares de embarque e desembarque de passageiros" (2010, p. 57).

(16) Na conceituação de Abreu, os museus-espetáculo "são edificados em escala global. Espaços enormes, edificações assinadas por renomados arquitetos contemporâneos, de altíssima tecnologia com realidade aumentada, $\mathrm{HQ}$ code, vídeos em 3D, holografias, experiências midiáticas inovadoras conjugadas com propostas arrojadas de gestão criativa e uma boa dose de empreendedorismo. Muitos destes museus são hoje efetivamente mais modernos que grande parte das empresas de ponta em diversos setores. Não há limite de criação para esses templos da cultura e do entretenimento" (2012, p. 14).

(17) Segundo os Anais dos Seminários de Capacitação Museológica: “A transformação de tal acervo em patrimônio público foi vista pelo ICFG e pelo Ministério da Cultura (MinC), por intermédio de sua secretaria de Patrimônio Museus e Artes Plásticas, como circunstância muito favorável à reunião de profissionais que atuam em instituições museológicas de todo o país em torno de um programa de capacitação nas áreas de museologia, restauro, artes, história, pesquisa, educação patrimonial, em razão de dois objetivos principais: garantir que o processo de institucionalização do acervo que se tornará museu seja transparente, aberto, participativo, aglutinando diversos atores sociais que uma ação desse tipo envolve, e contribuir para a atualização das formas de administrar espaços museológicos no Brasil“ (ICFG, 2004, p. 14).

(18) Nosso objetivo era ter um público bem popular, uma vez que íamos trabalhar num terreno para difundir um conhecimento popular, e era preciso restituir uma identidade, um interesse ao trabalho manual e ao trabalho técnico. Aliás, era preciso se situar num lugar onde o público já estivesse antes. Foi por isso que pensamos na possibilidade de fazer esse museu numa estação de metrô. Agora, se vamos falar em percentagem, não serei capaz de dar percentagens, mas, digamos, podemos pensar em um milhão de usuários do metrô. É evidente que aqueles que queremos atingir é o público da periferia urbana, que não tem, forçosamente, muitos espaços culturais à disposição. São pessoas que, nós sabemos, estão cansadas à noite, quando voltam do trabalho. Se queremos que elas venham ao museu por um tempo, é preciso atraí-las, mas não com grandes teorias. Em compensação, sabemos que é um espaço facilmente acessível para elas, porque há o metrô. Por outro lado, nossa atividade com o público é bem objetiva, e com certeza há atividades que serão feitas na estação, e até mesmo dentro do metrô. (...) Portanto, já temos a oportunidade de fazer contatos e propostas, pois esse é um museu por si mesmo aberto aos outros. E este era, sobretudo, o objetivo (Catel, 2005, p. 326).

(19) O programa Valor Social é realizado pelo Museu desde 2008, no qual o MAO oferece a jovens moradores de zonas economicamente menos favorecidas em Belo Horizonte e Nova Lima, estudantes da rede pública de ensino, a oportunidade de se capacitarem para uma atuação como conservadores, assistentes de restauradores, no mundo do trabalho. Para mais informações ver: MUSEU DE ARTES E OFÍCIOS. Programa Valor Social - ICFG. Disponível em: http://www.mao.org. br/port/vs_default.asp Acesso em: 18 jun 2012. 
(20) Trilhos da Memória (2002), Exposição de Grafite do Programa Fica Vivo! (2006), Revelados (2008), Visita da Família Real Belga ao Brasil (2011), Atlas Ambulante: Artesanias em trânsito (2011), A casa é sua (2011). Para mais informações a respeito dessas exposições ver: MUSEU DE ARTES E OFÍCIOS. Exposições Temporárias. Disponível em: http://www.mao.org.br/port/ exposicoes.asp Acesso em: 18 jun 2012.

\section{Referências}

ABREU, R. (2012). "Museus no contemporâneo: entre o espetáculo e o fórum". In: LOURES OLIVEIRA, A. P. P. e MONTEIRO OLIVEIRA, L. (orgs.). Sendas da Museologia. Ouro Preto, UFOP.

AMAZONAS, A. R. e LIMA, C. L. C. (2010). "Museus e desenvolvimento local: território e comunidade”. In: I SEMINÁRIO DE INVESTIGAÇÃO EM MUSEOLOGIA DOS PAÍSES DE LÍNGUA PORTUGUESA E ESPANHOLA. Actas, v. 1, Porto, Faculdade de Letras.

BARREIRA, I. A. F. (2010). Pulsações no coração da cidade: cenários de intervenção em centros urbanos contemporâneos. Caderno CRH, Salvador, v. 23 n. 59, pp. 255-266.

BOAVIDA, T. (2010). Os museus, o patrimônio e as dinâmicas urbanas: o caso de Coimbra. Informação ICOM Portugal. Série II, n. 8. Portugal.

BOTELHO, T. R. (2005). Revitalização de centros urbanos no Brasil: uma análise comparativa das experiências de Vitória, Fortaleza e São Luís. Revista Eure. Santiago do Chile, v. XXI, n. 93, pp. 53-71.

BOURDIEU, P. e DARBEL, A. (2003). O amor pela arte: os museus de arte na Europa e seu público. São Paulo, Edusp/Zouk.

BRASIL. Ministério das Cidades (2007). Banco de Experiências. Proposta para Requalificação da área Central de Belo Horizonte. Disponível em: http://www.cidades.gov. br/images/stories/ ArquivosSNPU/Biblioteca/ReabilitacaoAreasUrbanas/BH_Proposta_Reabilitacao_Area_Central. pdf. Acesso em: 2 jun 2012.

CAMPICl, C. de P. F. et al. (2006). Interações cotidianas e produção de sentidos no hipercentro de Belo Horizonte. In: II ENECULT - ENCONTRO DE ESTUDOS MULTIDISCIPLINARES EM CULTURA. Salvador, Faculdade de Comunicação/UFBA.

CANÇADO, W. (2013). Corredor Cultural Estação da Artes: dilemas da participação. Minha Cidade. São Paulo, ano 13, n. 155.02, Vitruvius. Disponível em: http://vitruvius.com.br/revistas/read/ minhacidade/13.155/4763 Acesso em: 10 ago 2013.

CATEL, P. (2005). Museu de Artes e Ofícios, Belo Horizonte: afinal, como nascem os museus? (Entrevista concedida a Luciana Sepúlveda Köptcke). História, Ciências, Saúde-Manguinhos, v. 12 (suplemento), pp. 323-338.

CHOAY, F. (2001). A alegoria do patrimônio. São Paulo, Estação Liberdade/Editora Unesp.

CORRÊA, M. F. N. (2010). Encantamento e estranhamento: como moradores e não moradores de Belo Horizonte experimentam o Museu de Artes e Ofícios. Dissertação de mestrado. Rio de Janeiro, Universidade Federal do Estado do Rio de Janeiro/Museu de Astronomia e Ciências Afins. 
COUGO, M. (2007). Museus e sua utilização como atrativo turístico: um estudo em Belo Horizonte. Dissertação de mestrado. Belo Horizonte, Centro Universitário UNA.

CUNHA, M. N. B. (2012). "Comunicação e representação: as minorias étnicas e sociais em museus". In: LOURES OLIVEIRA, A. P. P. e MONTEIRO OLIVEIRA, L. (orgs.). Sendas da Museologia. Ouro Preto, UFOP.

DECRETO N. 13.798, DE 9 DE DEZEMBRO DE 2009. Disponível em: http://portal6.pbh.gov.br/dom/ iniciaEdicao.do?method=DetalheArtigo\&pk=1017732 Acesso em: 13 jun 2012.

FALCÃO, F. A. R. (2003). Uma reflexão sobre a utilização de museus como vetores de operações urbanas: Os casos dos museus Iberê Camargo e Guggenheim-Bilbao. Dissertação de mestrado. Porto Alegre, Universidade Federal do Rio Grande do Sul.

FRANCO, M. I. M. (2004). “Programa Museológico para o Museu de Artes e Ofícios: modelo de gestão”. In: SEMINÁRIOS DE CAPACITAÇÃO MUSEOLÓGICA. Anais. Belo Horizonte, ICFG.

GIFFONI, I. A. (2010). Belo Horizonte: da cidade planejada ao planejamento da cidade. Turismo na Praça da Estação. Dissertação de mestrado. Balneário Camboriú, Universidade do Vale do Itajaí.

(2011). Usos públicos do conjunto arquitetônico e paisagístico da Praça da Estação e Turismo. In: VIII SEMINÁRIO DA ASSOCIAÇÃO NACIONAL PESQUISA E PÓS-GRADUAÇÃO EM TURISMO ANPTUR. Balneário Camboriú, Universidade do Vale do Itajaí

HUYSSEN, A. (2000). Seduzidos pela memória: arquitetura, monumento, mídia. Rio de Janeiro, Aeroplano.

(2004). Mídias e discursos da memória. Revista Brasileira de Ciências da Comunicação. São Paulo, v. XXVII, n. 1.

ICFG (2004). SEMINÁRIOS DE CAPACITAÇÃO MUSEOLÓGICA. Anais. Belo Horizonte, ICFG.

JACQUES, P. B. (2004). Espetacularização urbana contemporânea. Cadernos PPG-AU/FAUFBA/ Universidade Federal da Bahia. Salvador, ano 2, número especial.

JAYME, J. G. e NEVES, M. de A. (2010). Cidade e espaço público: política de revitalização urbana em Belo Horizonte. Caderno CRH. Salvador, v. 23, n. 60, pp. 605-617.

JULIÃO, L. (2006). “Apontamentos sobre a história do museu”. Caderno de Diretrizes Museológicas 1. 2. ed. Brasília/Belo Horizonte, MinC/IPHAN/DEMU/Secretaria de Estado da Cultura/ Superintendência de Museus.

LEI N. 10.277, DE 27 DE SETEMBRO DE 2011. Disponível em: http://portal6.pbh.gov.br/dom/ iniciaEdicao.do?method=DetalheArtigo\&pk=1066636 Acesso em: 13 jun 2012.

LEITE, R. P. (2010). A exaustão das cidades: antienobrecimento e intervenções urbanas em cidades brasileiras e portuguesas. Revista Brasileira de Ciências Sociais, v. 25, n. 72, pp. 73-89.

MATTOS, Y. (2010). “Outras faces da museologia: o museu e a comunidade”. In: MATTOS, Y. e MATTOS, I. Abracaldabra: uma aventura afetivo-cognitiva na relação museu-educação. Ouro Preto, Editora UFOP.

MATTOS, Y. e MATTOS, I. (2010). Abracaldabra: uma aventura afetivo-cognitiva na relação museu-educação. Ouro Preto, Editora UFOP

MENESES, U. T. B. de (2004a). “O museu de cidade e a consciência da cidade”. In: SANTOS, A. C. M; KESSEL, C. e GUIMARAENS, C. (orgs.). Livro do Seminário Internacional Museus e Cidades. Rio de Janeiro, Museu Histórico Nacional. 
MENESES, U. T. B. de (2004b). "Patrimônio Cultural: Dentro e Fora do Museu". In: SEMINÁRIOS DE CAPACITAÇÃO MUSEOLÓGICA... Anais. Belo Horizonte, ICFG.

MIRANDA, A. de S. (2007). A gênese da preservação do patrimônio municipal de Belo Horizonte: movimentos sociais e a defesa da Praça da Estação. Dissertação de mestrado. Belo Horizonte, Universidade Federal de Minas Gerais.

MURTA, R. S. (2008). Patrimônio material e turistificação: um estudo sobre a Praça da Estação. Dissertação de mestrado. Belo Horizonte, Centro Universitário UNA.

OHTAKE, R. (2000). Os novos monumentos das metrópoles. São Paulo em perspectiva. Disponível em: http: www.scielo.br/scielo.php. Acesso em: 5 maio 2012.

OLIVEIRA, R. D. (2008). Revitalização patrimonial. Revista eletrônica do Mestrado em Administração, Unisantos: Patrimônio: Lazer e Turismo, Edição n. 3.

QUEIRÓS, J. (2007). O lugar da cultura nas políticas de reabilitação de centros urbanos: apontamentos a partir do caso do Porto. IS Working Papers. Porto, n. 17, Universidade do Porto, Faculdade de Letras - Instituto de Sociologia.

SALES, A. A. M. (2010). Patrimônio cultural e gestão: o Museu de Artes e Ofícios de Belo Horizonte. Revista eletrônica do Mestrado em Administração Unisantos: Patrimônio: Lazer e Turismo. v. 7, Edição n. 11.

SMITH, N. (1996). The new urban frontier: gentrification and the revanchist city. Nova York/London, Routledge.

(2003). "La gentrification généralisée: d’une anomalie locale à la 'régénéracion urbaine' comme estretégie urbaine globale". In: BIDOU-ZACHARIASEN, C. (ed.). Retours en ville: des processus de gentrification urbaine aux politiques de revitalization des centres. Paris, Descartes \& Cie., pp. 45-72.

TOSTES, V. L. B. (2004). “Museus e cidades: um desafio contemporâneo”. In: SANTOS, A. C. M.; KESSEL, C. e GUIMARAENS, C. (orgs.). Livro do Seminário Internacional Museus e Cidades. Rio de Janeiro, Museu Histórico Nacional.

VARGAS, H. C. e CASTILHO A. L. H. (orgs.). (2006). Intervenções em centros urbanos. Objetivos, estratégias e resultados. São Paulo, Manole.

VAZ, L. F. (2004a). “O papel dos equipamentos culturais na revitalização urbana”. In: SANTOS, A. C. M.; KESSEL, C. e GUIMARAENS, C. (org.). Livro do Seminário Internacional Museus e Cidades. Rio de Janeiro, Museu Histórico Nacional.

(2004b). A “Culturalização" do planejamento da cidade: novos modelos? Cadernos PPG-AU/ FAUFBA. Territórios Urbanos e Políticas Culturais. Salvador, v. 2, número especial, pp. 31-41.

Texto recebido em 11/out/2013

Texto aprovado em 20/mar/2014 
